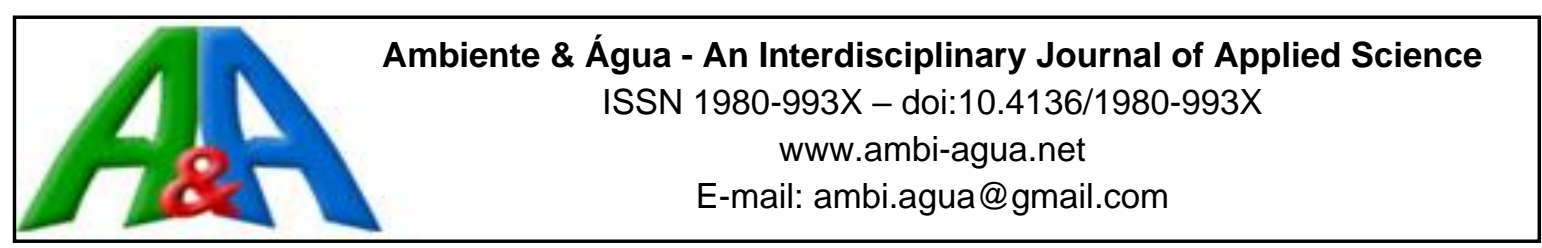

\title{
Energetic aspects and opportunities for reusing water on offshore platforms in Campos Basin, Brazil
}

\author{
doi:10.4136/ambi-agua.2121 \\ Received: 05 Apr. 2017; Accepted: 05 Jul. 2017

\begin{abstract}
Victor Magalhães Duarte*; Luciano Matos Queiroz; Ednildo Andrade Torres; Asher Kiperstok
\end{abstract}
Universidade Federal da Bahia (UFBA), Salvador, BA, Brasil
Centro Interdisciplinar em Energia e Ambiente (CIENAM)
*Corresponding author: e-mail: prema2023@hotmail.com, lmqueiroz@ufba.br, ednildo@ufba.br, asher@ufba.br

\begin{abstract}
In the drilling and production of oil at sea, a large quantity of potable water used is most commonly transported to oil platforms using offshore supply vessels (OSVs). Sea water desalination is used as well, but only in a few oil platforms. To minimize energy consumption, water supply options were studied. The desalination of seawater and the reusing of streams of grey water and black water were evaluated and compared with the characteristics of the current supply via OSVs. In both desalination and OSV water supply options an electrolytic wastewater treatment plant is used. The objective of this study was to analyze the current situation regarding water supply on offshore platforms located in the Campos Basin, Rio de Janeiro, Brazil, and to propose measures to take advantage of opportunities to reuse water and reduce energy expenditure. Two alternative scenarios were developed that involved the reuse of water that comes from the effluent of a biological wastewater treatment plant (WWTP). Information on the logistics of supplying water to platforms was obtained through direct consultation with companies and sources in the literature. The results show that annual energy consumption (uptake, treatment, transportation, use and waste water treatment) of water on offshore platforms is currently $1.89 \mathrm{GWh}$, and that a reduction of $1.8 \mathrm{GWh}$ of the energy consumed can be achieved using advanced reuse treatments. Energy consumption in the water reuse treatment is more competitive than those of transport by OSVs or seawater desalination.
\end{abstract}

Keywords: energy, offshore supply vessel, water, wastewater treatment.

\section{Aspectos energéticos e oportunidades para reusar água em plataformas offshore na Bacia de Campos, Brasil}

\section{RESUMO}

Na perfuração e produção de petróleo no mar, uma grande quantidade de água potável utilizada é mais comumente transportada para plataformas de petróleo usando rebocadores. A dessalinização da água do mar também é usada, mas somente em algumas plataformas.Para minimizar o consumo de energia, opções de abastecimento de água foram estudadas. A dessalinização da água do mar e a reutilização de água cinza (clara e escura) e água negra foram avaliadas e comparadas com as características do fornecimento de água através de rebocadores. 
Tanto no suprimento de água por dessalinização quanto por rebocadores, o tratamento de esgoto eletrolítico é usado. O objetivo deste estudo foi analisar a atual situação do abastecimento de água em plataformas offshore localizados na Bacia de Campos, Rio de Janeiro, Brasil, e propor medidas para obter vantagens das oportunidades de reutilização de água e reduzir o consumo de energia. Dois cenários alternativos foram desenvolvidos. Essas opções envolvem o reúso de água que vem do efluente de uma planta de tratamento biológico de esgoto (ETE). Informações sobre a logística de fornecimento de água potável para as plataformas foram obtidas através de consulta direta com empresas e fontes na literatura. Os resultados mostram que, atualmente, o consumo anual de energia (captação, tratamento, transporte, uso e tratamento de esgoto) para fornecimento de água a uma plataforma offshore é igual a 1,89 GWh. Uma redução de 1,8 GWh da energia consumida pode ser conseguida, usando tratamentos avançados de reúso de água. $\mathrm{O}$ consumo de energia no tratamento para reuso de água é mais competitivo do que o transporte via rebocador ou a dessalinização de água do mar.

Palavras-chave: água, energia, rebocadores, tratamento de esgoto.

\section{INTRODUCTION}

The exploration and production of oil in the ocean requires a significant amount of energy to supply water to offshore oil platforms. This water is mainly for domestic uses (showers, toilet flushing, laundry, and the washing of dishes, fruit and vegetable, and decks). The main contaminant in the deck-washing wastewater is the oil residue accidentally spilled during maintenance operations or oil that adheres to the shoes of people working in areas with oil residue on floors.

Mineral water is used for drinking and cooking. This water is supplied in plastic 20-litre containers and delivered by OSVs.

In drilling platforms and oil production operated by Petrobras (Petróleo Brasileiro SA) in the Campos Basin, Rio de Janeiro, Brazil, water is supplied by an offshore supply vessel (OSV). The water supply chain in this region begins with the uptake of raw water from the Macaé River. The water is discharged from the WTP (water treatment plant), and is then put into OSV storage tanks and transported for later delivery to platforms.

Due to the large amount of energy needed to supply water to offshore platforms using OSVs, possible alternative forms must be carefully evaluated, especially from an energy consumption perspective.

Water transport logistics for offshore platforms via OSV is a complex operation and has many limitations; it therefore depends directly on the characteristics of the type of vessel and its ability to handle weather and navigation conditions. The uncertainties constitute a major challenge for scheduling and routing and make it difficult to efficiently utilize the supply vessels based on a deterministic planning approach. These uncertainties force OSVs to constantly change their programs (Aas et al., 2009). Moreover, the logistical chain for water supply and wastewater treatment consumes a lot of energy and generates air pollution.

Transporting water from the wastewater treatment plant (WWTP) to 60 far-away platforms - approximately $200 \mathrm{~km}$ from the coast - requires 23 OSVs. Petrobras has a pier in the city of Macaé, Rio de Janeiro for water loading and other products that will be transported to the platforms. The WWTP is close to the pier, but is at a higher level, which facilitates the transportation of water using gravity. The OSV tanks are filled with water, which takes approximately five hours. The type of OSV that is used most often in the Campos Basin to carry water has a capacity of up to $2,000 \mathrm{~m}^{3}$ per trip. The amount of water carried on each trip should supply up to four platforms. Every year, 548 OSV trips are carried out to supply the Petrobras 60 platforms in the Campos Basin with water for domestic consumption. After use, the majority of the water is routed for treatment at a WWTP and then discharged into the ocean. 
In treatment systems installed in Brazilian sanitation companies, the average electricity consumption is $0.72 \mathrm{kWh} \mathrm{m}^{-3}$ (Gomes, 2013). The water for the platforms in the Campos Basin comes from a WWTP in the city of Macaé, and $1.46 \mathrm{kWh}$ of energy per cubic meter is needed to uptake and treat it (Lemos, personal communication, 2015). This high-energy consumption is due to the need for water from the Macaé River to be pumped into water tanks at the top of a mountain before reaching the WWTP by gravity.

Reusing water on oil rigs is presented as an alternative that could prove less harmful to the environment when compared with OSV transportation of water (Duarte et al, 2015). This article only evaluated two alternatives to supply water in offshore platforms other than OSVs and desalination using reverse osmosis, although distillation is used to desalinate water as well. Both alternatives of the reuse of effluent generated in the biological wastewater treatment use a purification chain, mainly with a membrane filtration process. With regard to energy, membrane technology for seawater desalination consumes less power than the distillation process (Sarte et al., 2006; Al-Qaranghouli and Kazmerski, 2012). In distillation with vapor compression, the energy consumption of the process is about 7 to $12 \mathrm{kWh} \mathrm{m}^{-3}$, while that for reverse osmosis (RO) is 4 to $6 \mathrm{kWh} \mathrm{m}^{-3}$ (sea water) (Al-Qaranghouli and Kazmerski, 2012). However, the energy consumption of RO to treat brackish water is $1.0 \mathrm{kWh} \mathrm{m}^{-3}$ (Dolnicar and Schäfer, 2006). Although RO results are effective, the configuration of their membranes is susceptible to a wide variety of organic, inorganic, particulate/colloidal, and biological fouling (Amjad, 1992). To mitigate membrane fouling and to prevent damage from occurring, RO systems require a sufficient and reliable pre-treatment to produce a higher-quality feed of water to ensure stable, long-term performance of the RO membrane elements, regardless of changes in turbidity of raw water (WHO, 2007; Wolf and Siverns, 2004). Although this pre-treatment has been done for many years by using chemicals, more common today is the use of ultrafiltration (UF) membranes (Beery, 2010).

While most platforms in the Campos Basin are fitted with electrolytic WWTPs, mainly due to the lower weight of the structure and compactness compared to biological WWTPs, these units have limitations that make it less attractive for incorporation with projects that aim to reuse water. Limitations are as follows: the electrolytic WWTPs consume almost two times more energy than biological WWTPs for the same amount of wastewater treated (Czerviski, 2001); daily they generate $0.8 \mathrm{~kg}$ waste person ${ }^{-1}$ after centrifugation; the centrifugation and storage of waste requires room on the platform and requires skilled labor; frequent cleaning of electrolytic cells (Czerviski, 2001) undermines the full utilization of the effluent; in times of peak water consumption, the contact time with chlorine appears inadequate to oxidize the organic matter, reducing the efficiency of the treatment; and neutralizing an excess of chlorine in the effluent requires sodium bisulphite solution storage tanks, occupying more space and increasing the total weight of the unit (The Dow, 2015; Upsher and Fletcher, 1996). In the biological WWTPs, the sludge is only removed every six months.

Given this scenario, we propose an analysis of the energy aspects, challenges and opportunities for implementing the reuse of water in offshore platforms located in the Campos Basin, Rio de Janeiro, Brazil.

\section{MATERIALS AND METHODS}

The literature review consisted of consulting scientific articles in indexed journals on seawater desalination and reclaimed water directly from wastewater effluent. The review indicated that lighter systems were preferred because they occupied less space than units used on land; optimizing the use of space and limiting weight were basic requirements in any design for offshore platforms. On the other hand, techniques and equipment with lower power 
consumption were also sought after, and determining such techniques and equipment was the goal of this article.

In order to identify the use and distribution of water for domestic use on an offshore platform, contact was made with the person responsible for this on a platform to advise the uses and respective amounts of water.

Data was collected from various sources. Biological and electrolytic WWTPs for use on platforms were not addressed in scientific articles. This research therefore collected the required data through technical manuals and the information regarding the platforms through technical visits. Details of the OSVs and the trip characteristics (time, distances travelled, and types of engines used) were provided by the companies who rent the OSVs in the area under study and by the logistics of the Brazilian oil company. Fuel consumption calculations were obtained using technical data from the OSV manufacturers (Solstad Farstad, 1999), to include the different operating conditions of the engine and its functioning time. These data, along with energy consumption of electrolytic and biological WWTPs, formed the basis for energy consumption calculations in the current conditions and the proposed alternative scenarios.

In Brazil, there are currently two options for supplying offshore oil platforms with water. The first is completely described by Duarte et al. (2015). In this option, water is collected at the WWTP (at the pier), transported by OSVs, discharged into the platform tanks, used, and forwarded to an electrolytic WWTP. Finally, the effluent is discarded into the sea. The water used in the deck washing is sent to the oil and water separator and disposed of into the sea after reaching a concentration of $15 \mathrm{mg} \mathrm{L}^{-1}$ or less.

Typical water consumption in an offshore platform of 190 people is shown in Table 1.

Table 1. Daily water consumption in an offshore platform with 190 people.

\begin{tabular}{lc}
\hline $\begin{array}{c}\text { Point of } \\
\text { Consumption }\end{array}$ & $\begin{array}{c}\text { Quantity of water } \\
\text { consumed (L) }\end{array}$ \\
\hline Toilet flush & 6,840 \\
Showers & 18,240 \\
Sinks basins & 4,050 \\
Galley & 14,670 \\
Laundry & 2,070 \\
Deck washing & 4,008 \\
\hline Total & $\mathbf{5 0 , 3 2 8}$ \\
\hline
\end{tabular}

Source: SABESP (2000).

In the second option, seawater is collected and treated by both UF and RO filtration membranes. As depicted in the flow chart, the treatment of sewage is sent to an electrolytic WWTP and the effluent as well as UF and RO concentrates are discharged into the ocean (Figure 1). To supply the RO unit, seawater must be captured at an average ocean depth of 30 meters and with an approximate flow rate of $25 \mathrm{~m}^{3} \mathrm{~h}^{-1}$.

Scenario 1 proposes reuse of the water produced from the biological WWTP that is generated on the platform. 


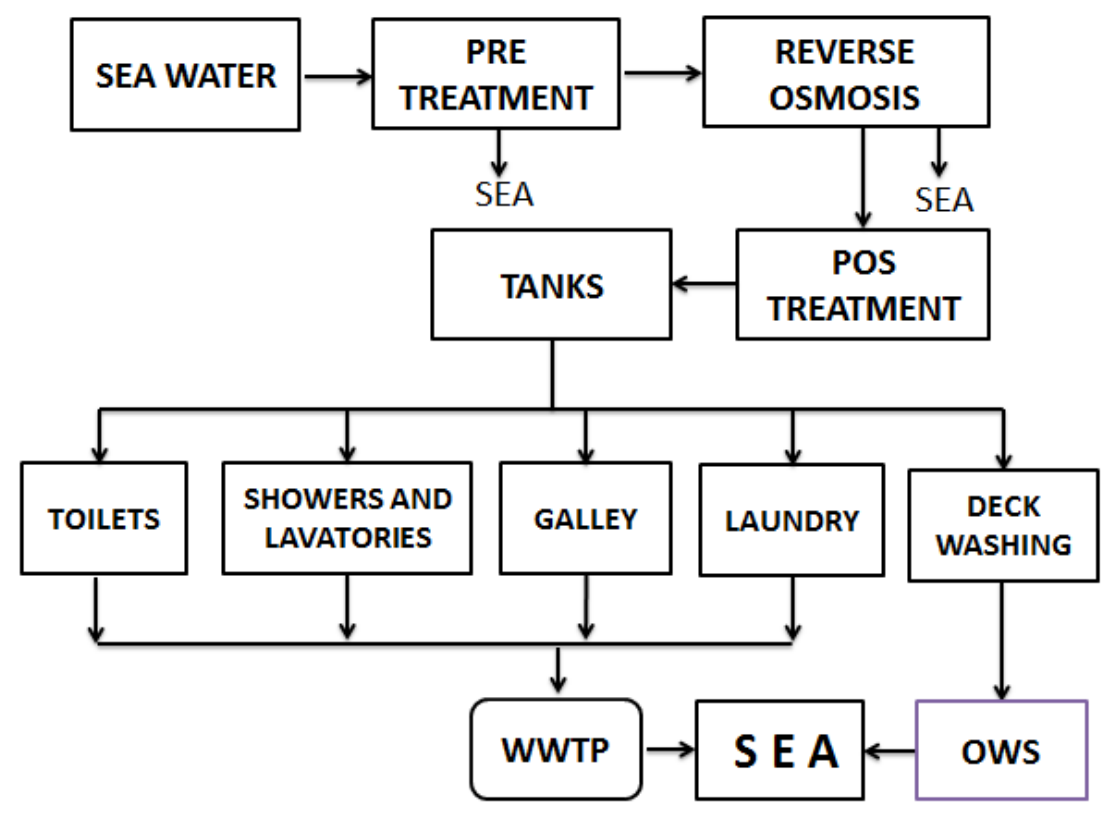

Figure 1. Desalination of seawater and water use.

In scenario 1, the black, gray and oily waters are sent to the same biological WWTP. (Figure 2); but the oily water from the deck washing initially passes through an oil and water separator (OWS) and is then sent to the biological WWTP. The effluent concentration exiting the OWS is at most $15 \mathrm{mg} \mathrm{L}^{-1}$. The amount of water used per day to wash the decks (4,000 liters) represents a load to be degraded equivalent to the sewage generated by two people, which the biological WWTP has capacity to treat. The light gray water (the wastewater from showers, washbasins and laundry) passes through a fine sieve to retain solid particles (hair and tissue fibers) and is directed to the biological WWTP. The dark gray water (wastewater from the galley) passes through a fine sieve and then a grease trap (GT) before being directed to the biological WWTP.

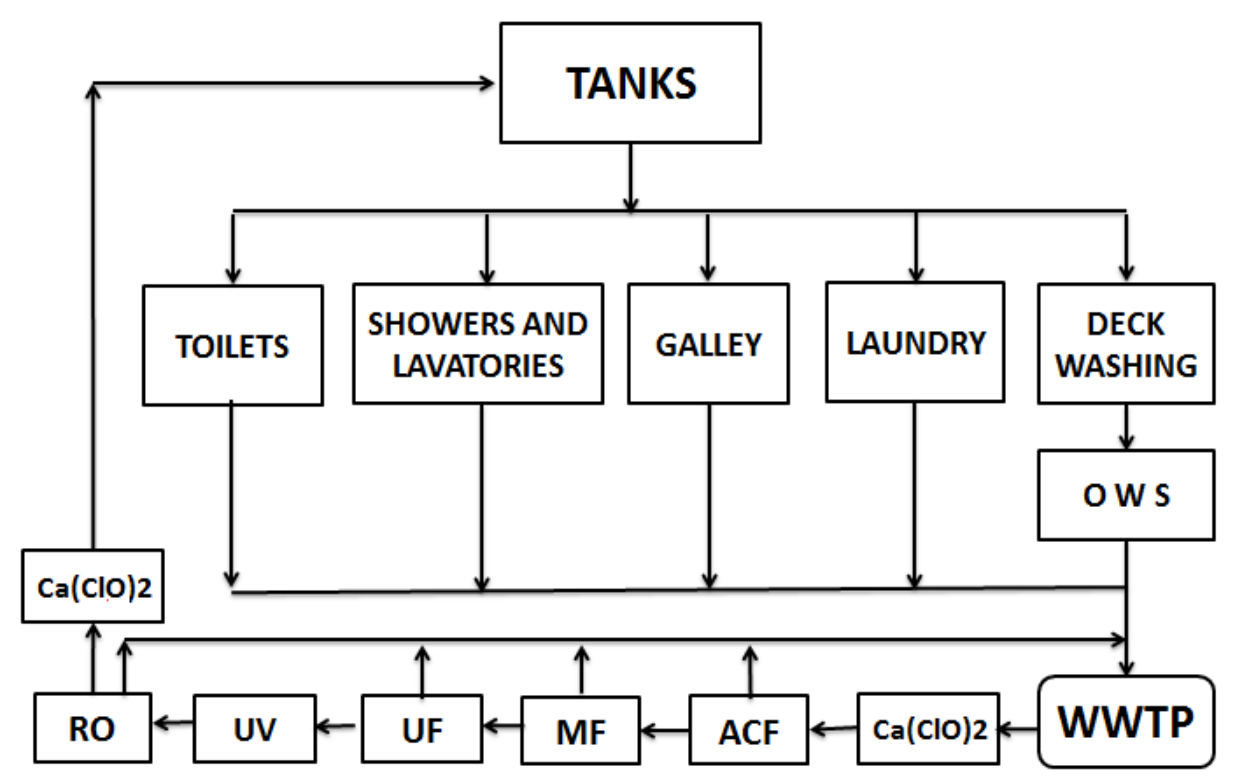

ACF Activated Carbon Filter MF Microfiltration UF Ultrafiltration RO Reverse Osmosis UV Ultraviolet

Figure 2. Scenario 1 - Water reuse from the treated wastewater effluent. 
The effluent initially passes through disinfection with calcium hypochlorite and an activated carbon filter to remove excess of chlorine to preserve MF and UF membranes. Then the effluent undergoes microfiltration and ultrafiltration to remove larger microorganisms (protozoa and bacteria) and reduce turbidity. The application of UV radiation and RO removes viruses, providing a water quality in compliance with Brazilian Ministerial Order 2914/2011.

The Quantitative Microbial Risk Assessment (QMRA) was used to evaluate the microbial quality of water after being treated (Westrel, 2004; Howard et al., 2006; Canada, 2011; 2012). It was considered that the flow rates from the backwashing of MF, UF and RO could also be returned and treated by the WWTP.

To purify the effluent from the biological WWTP, techniques already designed and approved for direct potable reuse (DPR) were used. In Scenario 1, the water loss during sludge disposal is $25 \mathrm{~m}^{3}$, which is in accordance with the biological WWTP requirements. The majority of water losses (evaporation during deck washing and sludge disposal) are replaced by urine (about 400 litres per day) which is fed into the WWTP. If more water is required it can be obtained according to the platform water supply plan. In this scenario, the energy-consuming equipment is comprised of three pumps for pressurization (UF, discard the OWS, backwash and RO equipment).

Although the water in Scenario 1 has been treated, it is not intended for human consumption. However, because it can be used in situations that may involve involuntary intake (bathing and brushing teeth), the water quality must be compatible with water that will be consumed.

In Scenario 2, as in Scenario 1, all wastewater, including the stream from the deck washing, goes into the WWTP and is fully reused. But in this scenario the WWTP uses a membrane bioreactor (MBR). In the treatment process train, after the WWTP, the effluent is chlorinated to inactivate virus and avoid regrowth of pathogens in the process train ahead. The activated carbon filter (ACF) removes organic matter and chlorine to avoid damage in RO membrane. The next step is an advanced oxidation process (AOP) to eliminate organic matter in the effluent and reduce RO fouling. Finally, after reverse osmosis (RO) treatment, the effluent is chlorinated again to keep a residual in the water to avoid biological contamination during storage (Figure 3).

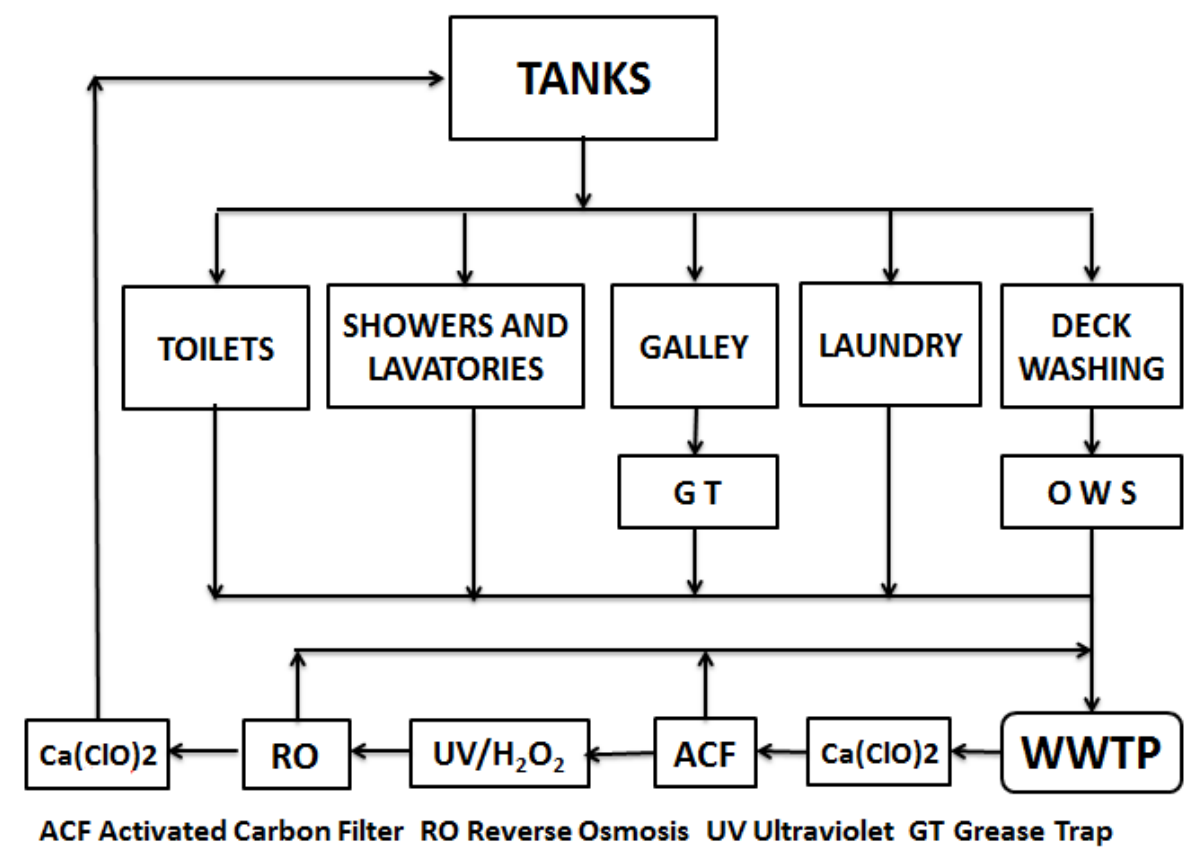

Figure 3. Scenario $2-$ Water reuse from the treated wastewater effluent.

In Scenario 2, the energy-consuming equipment is comprised of three pumps for pressurization (discard the OWS, backwash and RO equipment). 
The different stages that include travel (round trip) from OSVs to provide water to the platforms must consider timing: on the pier, the outward trip, the return trip, and during the water discharge on the platform. These are the steps with variable times: waiting during the trip, leaving, and returning. However, for the purposes of calculating maritime diesel oil (MDO) consumption and estimating the amount of energy spent in transporting water via OSVs, in addition to the known fixed times, the most common variable times were chosen.

In the implementation of one of the alternative systems, water transport by the OSV is used only in the case of interrupting the desalination operation or interrupting the water-reuse systems. This is because the systems of Scenarios 1 and 2 are self-sustaining.

In order to calculate the amount of energy consumed in the transportation of water to the platforms, the standard trip of the OSV was used, which, due to the needs of each platform and the water transport logistics, carry $2,000 \mathrm{~m}^{3}$ of water in each trip, which is shared by four platforms (500 $\mathrm{m}^{3} /$ trip / platform). Therefore, in the items of ODM consumption that correspond to the stages of the round trip of the OSV, the quantity of ODM and the respective amount of energy consumed for a platform is pro-rata, since the quantities were initially calculated for four platforms.

For calculating the energy in $\mathrm{kWh}$ spent in water transportation, it was necessary to transform MDO consumption into energy. OSVs use 2,610 kW and 1,056 kW engines, which have energy efficiencies of $44 \%$ and $42 \%$, respectively (an average of $43 \%$ was adopted) (Hitachi, 2016). As fuel consumption is known for each stage of water transportation, and one tonne of MDO is equal to $12,584 \mathrm{kWh}$ (The Carbon Trust, 2006), the amounts of energy could be calculated.

To determine the largest portion of energy savings among the options presented, the energy is consumed in each alternative is initially calculated. For supplying water by OSV the total amount of energy refers to the uptake, treatment and use of water, as well as water transportation. The amount of MDO consumed to transport the water must be calculated considering an efficiency of $43 \%$ in energy conversion in thermal electrical OSV generators that use MDO and a conversion factor of $12,584 \mathrm{kWh}$ tonne ${ }^{-1}$ of MDO (primary energy) (The Carbon Trust, 2006). The other options of water supply refer to the energy consumption of the equipment used in desalination and reuse, respectively. For the energy consumption in Scenario 1, Scenario 2 and desalination, the equipment manufacturer specifications were used. Using the total electric consumption per day divided by the water flow in $\mathrm{m}^{3}$, the energy in $\mathrm{kWh}$ per $\mathrm{m}^{3}$ could be defined. For the WWTP the oil company supplied the information required. With the energy consumption of each option, the higher and lower consumptions and the differences between them were chosen.

Water distribution is accomplished using a system named "hydrophore", which pressurized water from the tanks in the legs of platforms in order to reach each point of use.

\section{RESULTS AND DISCUSSION}

During the study period, the time it took to accomplish each step. The transporting of water by OSVs and their MDO consumption were surveyed regularly and showed minor variations. The steps with normally immutable times are: on the pier, the trip from pier to platform, discharging water on the platform, shifts among platforms and the trip back to the pier. For the other items related to waiting for the trip to the platform and the trip back, those with a higher frequency of occurrence (mode) were selected, as shown in Table 2. 
Table 2. Time and MDO consumption in each trip to the four platforms.

\begin{tabular}{lcc}
\hline \multicolumn{1}{c}{ Items of Consumption } & Time(Hours) & MDO Consumption (Tonne) \\
\hline On pier & 5 & 0.36 \\
Trip from pier to platform & 12 & 8.73 \\
Waiting in the trip to platform & 24 & 6.91 \\
Shifts among platforms & 9 & 6.54 \\
Water discharging in the platform & 20 & 5.76 \\
Waiting in the trip back & 10 & 2.70 \\
Trip back to pier & 10 & 2.88 \\
\hline Total & $\mathbf{9 0}$ & 33.88 \\
\hline
\end{tabular}

In 2013, $101.98 \mathrm{GWh}$ were consumed to provide $1,095,000 \mathrm{~m}^{3}$ of water for use on 60 platforms, with $1.60 \mathrm{GWh}$ in uptake and treatment and $100.38 \mathrm{GWh}$ in the transport of water by OSVs.

Table 3 shows the consumption of MDO and energy by platform per trip. The total MDO consumption for each platform is consumption per trip (8.47 tonnes) times the number of trips per year, or 309 tonnes.

Table 3. Consumption of MDO and energy by platform per trip.

\begin{tabular}{lcc}
\hline \multicolumn{1}{c}{ Items of Consumption } & MDOTonne & Energy Consumption MWh \\
\hline On pier & 0.09 & 0.49 \\
Trip from pier to platform & 2.18 & 11.81 \\
Waiting for the trip to platform & 1.73 & 9.35 \\
Shifts among platforms & 1.64 & 8.85 \\
Water discharging in the & 1.44 & 7.79 \\
platform & 0.67 & 3.65 \\
Waiting for the trip back & 0.72 & 3.90 \\
Trip back to pier & 8.47 & 45.84 \\
\hline Total & & \\
\hline
\end{tabular}

Table 4 shows the energy consumption of one platform supplied by OSV. The total energy consumption including the uptake, water treatment in the WTP, transportation, unloading, use and wastewater treatment for one platform in the Campos Basin, RJ, Brazil, was $5,178.5 \mathrm{kWh} \mathrm{day}^{-1}$ or $1.89 \mathrm{GWh} / \mathrm{year}$. The total energy consumption per day for 60 platforms is $310.71 \mathrm{MWh}$ (Table 4). 
Table 4. Energy consumption in the Scenario 1.

\begin{tabular}{lcc}
\hline \multicolumn{1}{c}{ Processes } & $\mathrm{kWh} /$ day/platform & MWh/day/60platform \\
\hline Water Production & 37.0 & 2.22 \\
Uptake & 36.0 & 2.16 \\
Treatment & & \\
Transport & 48.5 & 2.91 \\
Water supply on the pier & 1180.5 & 70.83 \\
One-way trip to platform & 935.0 & 56.10 \\
Waiting on the way going (in DP*) & 885.5 & 53.13 \\
Travel between platforms & 779.0 & 46.74 \\
Discharge water on platform & 365.5 & 21.93 \\
Waiting in back & 389.5 & 23.37 \\
Return to the pier & & 1.23 \\
Water Supply & 20.5 & 1.23 \\
Platform supply & & $\mathbf{3 1 0 . 7 1}$ \\
Water Use & 20.0 & \\
Water use in platform & & \\
Wastewater Treatment System (WWTP) & $\mathbf{5 , 1 7 8 . 5}$ & \\
Water pump to WWTP & & \\
Electrolytic WWTP (50 $\mathrm{m}^{3} /$ day) & & \\
\hline Total consumption & & \\
\hline DP-Dynic Posit. & & \\
\hline
\end{tabular}

*DP-Dynamic Position.

The energy consumption in one platform supplied by desalination is depicted in Table 5 . The total energy consumption including the uptake, pre-treatment with UF, desalination (RO) and water distribution is $746.0 \mathrm{kWh} /$ day. The total energy consumption per day for 60 platforms is $44.82 \mathrm{MWh}$ (Table 5).

Table 5. Energy consumption with water desalination.

\begin{tabular}{lcc}
\hline \multicolumn{1}{c}{ Processes } & $\mathrm{kWh} /$ day/platform & MWh/day/60 platform \\
\hline Seawater uptake & 11.0 & 0.66 \\
Ultrafiltration pump & 13.0 & 0.78 \\
Reverse osmosis pump & 210.0 & 12.60 \\
Water use (hydrophore) & 37.0 & 2.22 \\
Water pump to WWTP & 15.0 & 0.90 \\
Electrolytic WWTP & 461.0 & 27.66 \\
\hline Total consumption & $\mathbf{7 4 6 . 0}$ & $\mathbf{4 4 . 8 2}$ \\
\hline
\end{tabular}


Table 6 shows the energy consumption in one platform supplied by two different water reuse systems. Scenario 2 energy consumption is $46.2 \%$ less than Scenario 1.

Table 6. Energy consumption with water reuse.

\begin{tabular}{lcc}
\hline \multicolumn{1}{c}{ Processes } & $\mathrm{kWh}$ /day/platform (Scenario 1) & $\mathrm{kWh} /$ day/platform (Scenario 2) \\
\hline Biological WWTP & 134.4 & 47.5 \\
Discharge pump & 4.5 & 4.5 \\
Ultrafiltration pump & 12.8 & - \\
Backwashing pump & 6.4 & 6.4 \\
Oil Water Separator & 1.2 & 1.2 \\
Reverse osmosis pump & 35.5 & 35.5 \\
Ultraviolet & 0.9 & 0.9 \\
Water use (hydrophore) & 20.0 & 20.0 \\
\hline Total consumption & $\mathbf{2 1 5 . 7}$ & $\mathbf{1 1 6 . 0}$ \\
\hline
\end{tabular}

Table 7 compares the energy consumption of the current supply condition of water by OSVs to the offshore platforms in the Campos Basin and desalination with the two scenarios. Regarding energy consumption, the most advantageous option of water reuse is Scenario 2. It consumes $2.2 \%$ of the total energy of the OSVs, $15.5 \%$ of desalination and $53.8 \%$ of the Scenario 1 (Table7).

Table 7. Energy consumption of 60 offshore platforms in Campos Basin, Brazil.

\begin{tabular}{lcc}
\hline Water supplying & Daily consumption $(\mathrm{MWh})$ & Annual consumption $(\mathrm{GWh})$ \\
\hline OSV* $^{*}$ & 310.71 & 113.4 \\
Desalination & 44.82 & 16.4 \\
Scenario 1 (Reuse 1) & 12.94 & 4.7 \\
Scenario 2 (Reuse 2) & 6.96 & 2.5 \\
\hline
\end{tabular}

*Including energy consumption in the uptake, treatment in the WTP and treatment in the WWTP.

Compared with water carried by OSVs to offshore oil rigs, desalination reduces energy consumption by $97 \mathrm{GWh}_{\text {year }}{ }^{-1}$ and for water reuse reduces by $108.7 \mathrm{GWh}$ year $^{-1}$ in Scenario 1 and by $110.9 \mathrm{GWh}$ year $^{-1}$ in Scenario 2 . This means that for each platform the energy saved is about $1.8 \mathrm{GWh}$ year $^{-1}$ when water reuse is considered. However, the desalination process consumes 11.7 to $13.9 \mathrm{GWh}_{\text {year }}{ }^{-1}$ more energy than the water reuse systems.

Scenarios 1 and 2 are presented as viable alternatives for reducing electric power consumption, as can be seen in Table 7 in which the four conditions for the availability of 50 $\mathrm{m}^{3}$ day $^{-1}$ of water to each of the 60 platforms are compared. The losses in Scenario 1 occur on each platform every six months when the sludge is removed from the total amount of water $\left(25 \mathrm{~m}^{3}\right)$ of each biological WWTP.

The WWTP used in platforms is often electrolytic, with a consumption of 24 KVA of energy to treat $50 \mathrm{~m}^{3}$ a day. For a power factor of 0.8 and over 24 hours of continuous operation, 
the power consumption is $9.22 \mathrm{kWh} \mathrm{m}^{-3}$, with an annual total energy consumption of 168.26 MWh in each platform.

Biological wastewater treatment units consume less energy than electrolytic ones. While the biological unit consumes $134.4 \mathrm{kWh} \mathrm{day}^{-1}$ (Scenario 1) and $47.5 \mathrm{kWh} \mathrm{day}^{-1}$ (Scenario 2) to meet the needs of 190 people, treating black and grey water, the electrolytic unit consumes $230.5 \mathrm{kWh} \mathrm{day}^{-1}$.

Biological WWTP for water reuse in offshore platforms provides a stable and better quality effluent, and energy use is from $41.7 \%$ (Scenario 1) to $79.4 \%$ (Scenario 2) less than that of the electrolytic WWTP. Considering Scenario 2, the difference between the energy to run an electrolytic unit and a biological unit is $66.8 \mathrm{MWh} \mathrm{year}^{-1}$, which is enough to run four biological units for 351 days (Figure 4).

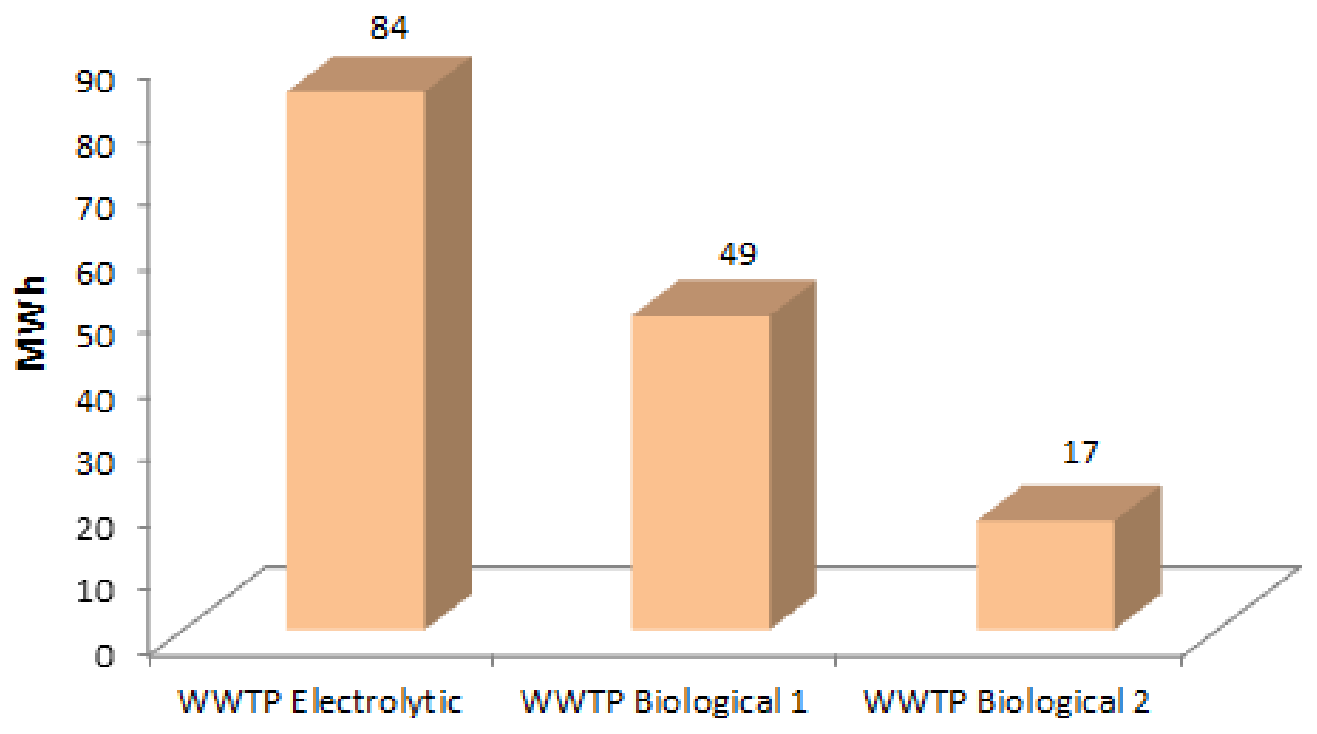

Figure 4. Annual energy consumption in MWh of the electrolytic and biological WWTPs.

When replacing the electrolytic with a biological WWTP (Scenario 2) that consumes less power, an annual energy savings of $11 \mathrm{GWh}$ is generated across 60 platforms. Moreover, reusing water provides energy efficiency to the water supply system for offshore platforms, allows the effective conservation of water sources and reduces the emission of both greenhouse gases and those harmful to health.

As reported by the Power Research Company of the Brazilian Ministry of Energy and Water, the average residential consumption of electricity in Brazil in 2012 was $161 \mathrm{kWh}$ month $^{-1}$ (Brasil, 2013). Considering OSV water supply for 60 platforms, the annual consumption is $113,4 \mathrm{GWh}$ (Table 7) minus the annual energy consumption of $2.5 \mathrm{GWh}$ in reuse (Scenario 2); the annual energy saved would be $110.9 \mathrm{GWh}$. This amount can supply 50,900 homes per year, calculated considering an average monthly consumption of $162 \mathrm{kWh}$. Figure 5 shows the number of homes that can be supplied with electricity in a year after saving $108 \mathrm{GWh}$ annually by reusing water (calculated at monthly consumption rates of $161 \mathrm{kWh}, 200$ $\mathrm{kWh}, 300 \mathrm{kWh}$ and $400 \mathrm{kWh}$ per household) (Figure 5).

The annual energy consumption for the supply of $1,095,000 \mathrm{~m}^{3}$ of water to 60 platforms is $108 \mathrm{GWh}$ or $1.8 \mathrm{GWh}$ for each platform. This value also takes into account uptake, water treatment and wastewater treatment (Table 8). 


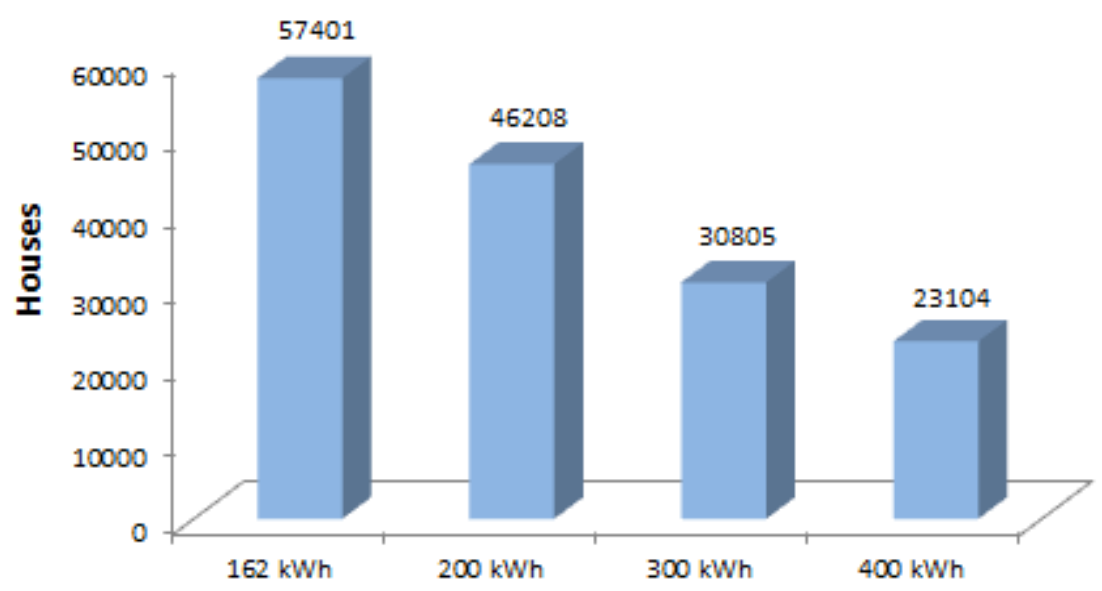

Figure 5. Number of houses that could be supplied with electrical energy saved in a year.

Table 8. Total annual energy consumption in water supply and wastewater treatments for 60 Platforms in the Campos Basin, Rio de Janeiro.

\begin{tabular}{lcc}
\hline \multicolumn{1}{c}{ Items of Consumption } & Annual Quantities & Energy $\left(\mathrm{GWh} \mathrm{year}^{-1}\right)^{*}$ \\
\hline Uptake and water treatment & $1,095,000 \mathrm{~m}^{3}$ water & 1.60 \\
On pier & 197 ton MDO & 1.06 \\
Trip from pier to platform & 4,778 ton MDO & 25.85 \\
Waiting for the trip to platform & 3,784 ton MDO & 20.48 \\
Shifts among platforms & 3,583 ton MDO & 19.39 \\
Water discharge from the platform & 3,153 ton MDO & 17.06 \\
Waiting for the trip back & 1,473 ton MDO & 8.00 \\
Trip back to pier & 1,572 ton MDO & 8.53 \\
Platform supply & $1,095,000 \mathrm{~m}^{3}$ water & 0.45 \\
Water use on platform & $1,095,000 \mathrm{~m}^{3}$ water & 0.44 \\
Electrolytic WWTP & $1,095,000 \mathrm{~m}^{3}$ wastewater & 10.54 \\
\hline Total in GWh/year & & $\mathbf{1 1 3 . 4 1}$ \\
\hline
\end{tabular}

*Secondary energy.

Energy consumption figures for water supplies of $500 \mathrm{~m}^{3}$ every ten days using OSVs (including energy consumed in the uptake, treatment and wastewater treatment) as compared with desalination and Scenarios 1 and 2 (depicted in Figure 6). 


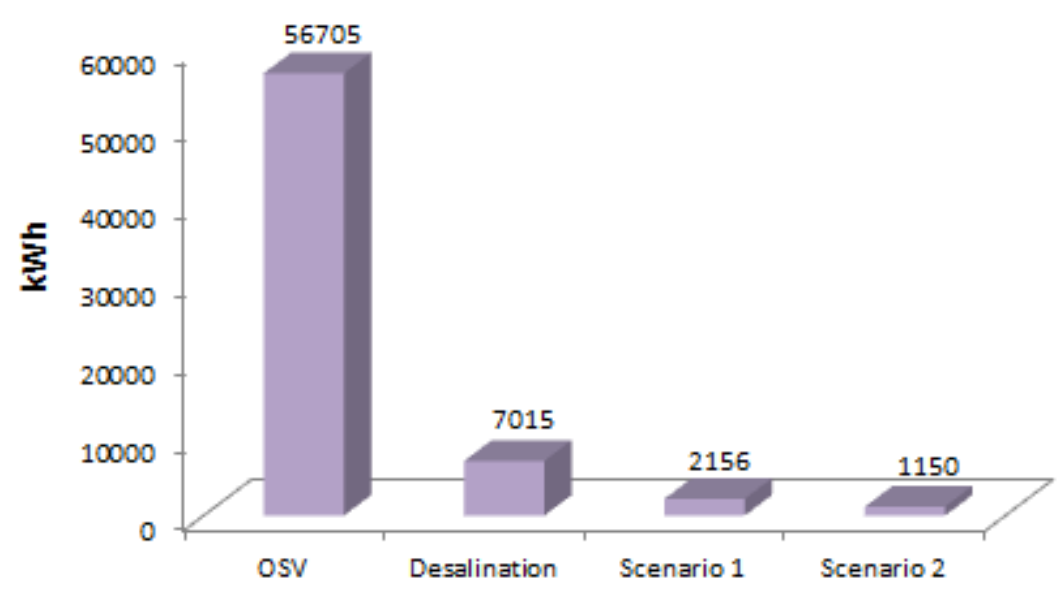

Figure 6. Energy consumption to supply $500 \mathrm{~m}^{3}$ of water in the 3 scenarios.

An oil production platform with 190 people daily consumes 72,000 kWh of energy. Because the annual energy savings by reusing water is $110.9 \mathrm{GWh}$, the energy saved is enough to power 4.2 platforms per year (Table 9).

Table 9. Energy saved with water reuse (60 platforms).

\begin{tabular}{lcc}
\hline \multicolumn{1}{c}{ Items of Consumption } & MWh day $^{-1}$ & GWh year $^{-1}$ \\
\hline OSV energy consumption* & 310.71 & 113.41 \\
Water reuse (Scenario 2) & 6.96 & 2.54 \\
\hline Total in GWh/year & & $\mathbf{1 1 0 . 8 7}$ \\
\hline
\end{tabular}

*Including uptake, treatment, transportation of water by OSV and waste water treatment.

As water reuse saves the total amount of water transported by OSV and each platform uses $50 \mathrm{~m}^{3}$ of water per day $\left(18,250 \mathrm{~m}^{3}\right.$ per year $)$, the total water saved for 60 platforms is more than $1,000,000 \mathrm{~m}^{3}$ per year.

According the results from QMRA calculation, the treated water from Scenarios 1 and 2 has a quality suitable for use in the galley, where dishes, fruit and vegetables are washed and exceeds the quality required for toilets and deck washing of the platform.

\section{CONCLUSIONS}

The high energy consumption and difficulties associated with supplying water to offshore platforms in Brazil makes desalination and water reuse viable alternatives. In addition, desalination and water reuse on oil rigs greatly reduce energy consumption compared with the water transport by OSVs. Water reuse projects that save water have been adopted in many countries. Reusing water on offshore platforms in the Campos Basin, Rio de Janeiro, Brazil is feasible, and once implemented will allow a savings of over 1,000,000 $\mathrm{m}^{3}$ of water per year.

As energy efficiency seeks to keep performing the same activities with lower power consumption, of the options studied, water reuse consumed the least energy. Therefore, the reuse of wastewater effluent on offshore platforms is vitally important, both in the logistics of its operation and in reducing energy consumption.

Replacing the electrolytic with a biological WWTP can save up to $4.0 \mathrm{GWh}$ per year in the 60 offshore platforms. 
Even though desalination water supply consumes between 11 and $13.9 \mathrm{GWh}$ more energy than water reuse yearly, it consumes 97 GWh less energy than OSV.

The reduction $\mathrm{f} 110.87 \mathrm{GWh}$ when water reuse is adopted compared with OSV shows that it is the best option to supply offshore platforms with water. This reduction means that each platform can save $1.8 \mathrm{GWh}$ per year when water reuse is considered.

When using water, reuse can provide a savings of $33.88 \mathrm{t}$ of MDO, which is the amount consumed on each trip of the OSV to provide $2,000 \mathrm{~m}^{3}$ of water to four platforms $\left(500 \mathrm{~m}^{3}\right.$ for each platform).

Finally, we conclude that the measures aimed at the reuse of biological wastewater effluent as presented in this article provide significant energy savings in the uptake, water treatment, water transport and electrolytic treatment of wastewater.

\section{REFERENCES}

AAS, B.; HALSKAU SR, Ø.; WALLACE, S. The role of supply vessels in offshore logistics. Molde University College, the Norwegian School of Logistics. Maritime Economics \& Logistics, v. 11, p. 302-325, 2009. 10.1057/mel.2009.7

AL-QARAGHOULI, A.; KAZMERSKI, L. L. Comparisons of technical and economic performance of the main desalination processes with and without renewable energy coupling. In: WORLD RENEWABLE ENERGY FORUM, 13-17 May 2012, Denver, Colorado. Proceedings... [S.1.]: ASES, 2012. p. 1-8.

AMJAD, Z. Reverse osmosis, membrane technology, water chemistry and industrial application. New York: Van Nostrand Reinhold, 1992. 384 p.

BEERY, M. Sustainable design of different seawater reverse osmosis desalination pretreatment processes. Computer Aided Chemical Engineering, v. 28, p. 1069-1074, 2010. https://doi.org/10.1016/S1570-7946(10)28179-8

BRASIL. Ministério das Minas e Energia. Empresa de Pesquisa Energética. Eficiência energética na indústria e nas residências. 2013. Available in: https://goo.gl/iUo1Bz. Access in: Aug. 2015.

CANADA. Health Canada. Guidelines for Canadian drinking water quality: enteric viruses. 2011. Available in: https://goo.gl/K8b2RS. Access: Jan. 2016.

CANADA. Health Canada. Guidelines for Canadian drinking water quality: enteric protozoa: Giardia and Cryptosporidium. 2012. Available in: https://goo.gl/WSe6ZN. Access: Jan. 2016.

CZERVISKI, D. Offshore marine sanitation devices. 2001. Available in: http://www.severntrentdenora.com/Products-and-Services/Marine-Sewage-TreatmentSystems/OMNIPURE/750.0003.2.pdf. Access in: May 2015

DOLNICAR, S.; SCHÄFER, A. I. Public perception of desalinated versus recycled water in Australia. In: ANNUAL AWWA DESALINATION SYMPOSIUM, 1., 7-9 May 2006, Honolulu, Hawaii. Proceedings... Denver: AWWA, 2006.

DUARTE, V.; KIPERSTOK, A.; QUEIROZ, L.; TORRES, E. Environmental efficiency in water use in offshore platforms in Campos Basin - RJ - Brazil. Journal of Water $\begin{array}{llllll}\text { Resource and Protection, } & \text { v. 7, } 015 .\end{array}$ http://dx.doi.org/10.4236/jwarp.2015.78050 
GOMES, A. S. Seminário gestão do uso da energia elétrica no saneamento: importância e dimensões do problema. Rio de Janeiro, 2013. Available in: www.aesbe.org.br/conteudo/anexo/1743. Access in: July 2015.

HITACHI ZOSEN CORPORATION. Power generator systems. 2016. Available in: https://goo.gl/cSJqYo. Access in June: 2016.

HOWARD, G.; PEDLEY, S.; TIBATEMWA, S. Quantitative microbial risk assessment to estimate health risks attributable to water supply: Can the technique be applied in developing countries with limited data? Journal of Water and Health, v. 4, n. 1, p. 49$65,2006$.

SARTÉ, B.; LEAHY, A. J.; ZICKLER, E.; TERRELL, M.; CAMPBELL, J. Water management challenges in the Loreto Region. 2006 Available in: https://goo.gl/xXSNhX. Access: July 2016.

SOLSTAD FARSTAD. Rem Ship As. Rem leader VS 499 LNG PSV platform support vessel. 1999. Available in: http://www.rem-maritime.no. Access: Aug. 2015.

THE CARBON TRUST. Energy and carbon conversion. 2006. Available in: http://www.inteltect.com/transfer/CT_Carbon_Conversion_Factsheet.pdf. Access in: Aug. 2016.

THE DOW CHEMICAL COMPANY. Filmtec Membranes: water chemistry and pretreatment: biological fouling prevention. Available in: https://goo.gl/nDrcuz. Access in: June 2015.

UPSHER, F. J.; FLETCHER, L. E. Review of chlorine and organohalides and their significance to the Royal Australian Navy. 1996. Available in: http://www.dtic.mil/get-tr-doc/pdf?AD=ADA311578. Access in: July 2015.

WESTRELL, T. Microbial risk assessment and its implications for risk management in urban water systems. 2004. 90p. Thesis (Doctorate in Water and Environmental Studies) - Linköping University, Linköping, 2004.

WORLD HEALTH ORGANIZATION - WHO. Desalination for safe water supply. Guidance for the health and environmental aspects applicable to desalination. Geneva, 2007. Available

in: http://www.who.int/water_sanitation_health/gdwqrevision/desalination.pdf. Access: July 2015.

WOLF, P. H.; SIVERNS, S. The new generation for reliable RO pre-treatment. In: INTERNATIONAL CONFERENCE ON DESALINATION COSTING, 2004, Limassol. Program and papers... Seeb: MEDRC, 2004. 